\title{
Articles
}

The Person and the Challenges

Volume 3 (2013) Number 2, p. 7-27

Jan Szczepaniak

The Pontifical University of John Paul II in Cracow, Poland

\section{The Liquidation of the Roman Catholic Clergy of the Latin Rite in the USSR (1917-1938)}

\begin{abstract}
After the peace treaty with Poland (18 March 1921) and after the reorganization of the Church administration in 1921 and in 1923, ten administrative units of the Catholic Church were placed within the borders of the USSR; eight were of the Latin rite and two of the Eastern rite. In this article, the author presents the history of repressions organized by the Soviet authorities towards the Roman Catholic Church (1917-1938) with special attention given to the process of liquidation of the Roman Catholic Clergy of the Latin rite.
\end{abstract}

\section{Keywords}

Catholic Church, Communist Revolution, totalitarian Regimes.

The Soviet authorities never really wanted to have a peaceful relationship between the state and the Catholic Church. Taking over the Tsarist policy of the marginalization of the Catholics and the limitation of the priesthood ministry by any means, the government aimed at the total liquidation of the hierarchy of the Church, its administrative structure and any signs of religious life. These actions were undertaken because of the following basic reasons. In the construction of 'the new society and country' there was neither a place for religion, nor for citizens strictly connected with foreign and political decision-making centres ${ }^{1}$. Basically, on

1 Г. Штриккера (ed.), Из программы РКП (б), принятой на VIII съезде партии (18-23 III 1918), in: Русская Православная Церковь в советское время (1917-1991). Материаль 
the whole territory of the USSR, being Catholic was associated with being Polish and at the same time, being subordinate to the Holy See (only in southern parts of Ukraine and in the Volga region it was also connected with being German)2

After the peace treaty with Poland (18 March 1921) and after the reorganization of the Church administration in 1921 and in 1923, ten administrative units of the Catholic Church were placed within the borders of the USSR; eight were of the Latin rite and two of the Eastern rite.

The Metropolitan Archdiocese of Mohilev, established in 1783 was the biggest administrative unit of the Roman Catholic Church. It covered the territory of the European Russia and also Belarus. It was evaluated by the diocesan authorities that 319354 Catholics with 108 priests in service (fifteen were imprisoned) lived within its borders in 1925 . The priestly ministry was present in 152 parish churches and subsidiary parishes. Moreover, services were held irregularly in 241 churches, chapels and oratories. There were a hundred priests outside the diocesan borders (mainly in Poland, Lithuania and Latvia) ${ }^{3}$.

The diocese of Minsk, which was established in 1798, covered the vast part of the Belarusian SSR (Soviet Socialist Republic). There were 150,000 Catholics, among whom there were only fifteen priests, who were in service in sixty six active parish churches and subsidiary parishes ${ }^{4}$ in the year 1923 on the territory of this diocese, which had already been under the Soviet influence.

In the northern part of the Ukrainian SSR there was the diocese of Zhitomir, erected in the place of the diocese of Kiev in 1798. It comprised seven parishes of the diocese of Lutsk, which was connected to Zhitomir by personal union. According to the office workers of the Zhitomir and Lutsk presbytery, there were 350,059 Catholics, 107 active parish and subsidiary churches ${ }^{5}$ within

и документы по истории отношений между государством и Церковью, v. 1, Москва 1995, p. 135.

2 D. J. Dunn, The Catholic Church and Russia. Popes, patriarchs, tsars and commissars, Aldershot 2004, p. 7; H. Stroński, Repressive measures of Stalinism towards the Polish population in Ukraine in the years1929-1939, Warsaw 1998, p. 65.

3 Elenchus cleri et ecclesiarum archidioecesis Mohiloviensis in Russia in diem 1 januarii $1925 \ldots$.. Varsavia 1924, p. 30.

4 Elenchus ecclesiarum et cleri saecularis ac regularis dioecesis Minscensis pro anno Domini 1923, [Nowogródek 1923], p. 25-30.

5 Elenchus venerabilis cleri saecularis et regularis dioecesium Luceoriensis et Żytomiriensis anno Domini 1923, Luceoriae 1923, p. 72. 
the borders of the diocese of Zhitomir in 1923. As Biłousow's research states, seventy six priests were working at that time in this particular diocese ${ }^{6}$.

The diocese of Kamianets was established at the end of the $14^{\text {th }}$ century and it was situated in the south-western area of the Ukrainian SSR. According to the parish and clergy catalogue from 1924, there were 300,000 Catholics on its territory ${ }^{7}$, who were enjoying the service of fifty priests $^{8}$. The faithful gathered in 102 parish churches and in fifty subsidiary churches and also in public chapels 9 .

The diocese of Tiraspol, constituted in 1848, covered the southern parts of the Ukrainian SSR and the Volga Region, which was a part of the Russian SSR. According to statistics conducted by bishop Józef Kessler, at the end of the 1920s, the diocese had 378,567 adherents, 125 parish churches and 154 subsidiary churches and 120 priests $^{10}$.

The diocese of Vladivostok established on the $3^{\text {rd }}$ February 1923, encompassed regions of Central Siberia and the Far East. This vast but not numerous diocese had 20,000 faithful in six parishes, where seven priests were in service ${ }^{11}$.

The south of Siberia and eastern part of Kirgizstan belonged to the Apostolic Vicariate of Siberia which was established on the $1^{\text {st }}$ December 1921. There were 75,000 Catholics and fifteen priests on this territory. The ministry service took place in thirty nine churches ${ }^{12}$.

The Apostolic Vicariate of Crimea and Caucasus was assigned from the southern part of the diocese of Tiraspol. There were 70,000 adherents and thirty priests working in fifty parish and subordinate churches, which belonged to that Vicariate.

6 Ю. Білоусов, Київсько-Житомирска римсько-католиика єпархія. Історичний нарис, Житомир 2000, p. 151-153.

7 Elenchus omnium ecclesiarum et universis cleri dioecesis Camenecensis pro anno Domini 1924, Buczacz 1924, p. 32; W. Rosowski, The History of the Roman Catholic Diocese of Kamianets in the years 1918-1941, Lublin 2008, p. 150.

8 Ibidem, p. 201.

9 Ibidem, p. 70-71.

${ }^{10}$ D. Brandes, Von den Zaren adoptiert: die deutschen Kolonisten und die Balkansiedler in Neurussland und Bessarabien 1751-1914, München 1993, p. 289-290; Я. Е. Дитиц, История поволжских немиев-колонистов, Москва 1997, p. 280-290; О. А. Лиценбергер, Римскокатолическая Церковь в России история и правовое положение, Саратов 2001, p. 349-353.

${ }_{11}$ Т. Козлов, Владивосток, in: Католическая энииклопедия, edit. Г. Церова and others, v. 1, Москва 2002, col. 1030.

${ }^{12}$ Elenchus cleri et ecclesiarum archidioecesis Mohiloviensis in Russia in diem 1 januarii 1923..., Varsavia 1923, p. 38-41. 
The apostolic administration for the Catholics of the Armenian rite was established in Tbilisi. It comprised forty five churches, 66,000 of the faithful and forty seven priests ${ }^{13}$.

For the Catholic Russians, who wanted to keep the Eastern rite, the exarch in Petersburg was constituted ${ }^{14}$.

One of the most serious problems connected with the Church administration in the Soviet Union was the lack of bishops. In 1919 the Soviet authorities discharged archbishop Edward Ropp from the Archdiocese of Mohilev, and in 1924 the apostolic administrator bishop Jan Cieplak, imprisoned from $1922^{15}$, was also expelled. In the diocese of Minsk, bishop Zygmunt Łoziński, who was imprisoned in Moscow from September 1920, was deported to Poland in $1921^{16}$. The bishop of the diocese of Zhitomir and Lutsk bishop Ignacy Dub-Dubowski left the diocese in June 1920 together with the retreating Polish army for fear of Soviet repression ${ }^{17}$ The bishop of Kamianets Piotr Mańkowski did the same thing in July $1920^{18}$ and the bishop of Tiraspol, J. Kessler left the territory of the diocese, which was under Soviet influence, in January 1920 for fear of being arrested, and he moved to a diocese in Moldavia ${ }^{19}$. None of the above mentioned bishops came back to the Soviet Union. They formally administrated the dioceses with the help of vicars general, who had been assigned by the bishops themselves, until Pius XI reorganized the Church administration in 1926. Bishop Karol Śliwowski, the bishop of Vladivostok was under the constant supervision of the security services; furthermore, he did not have the possibility of performing Christian ministry ${ }^{20}$,

${ }^{13}$ R. Dzwonkowski, Kościół katolicki w ZSSR 1917-1939. Zarys historii, Lublin 1997, p. 49.

14 А. Юдин, Леонид Федоров, in: Католическая эниңиклопедия, edit. Г. Церова, v. 2, Москва 2005, col. 1622-1623.

${ }^{15}$ D. J. Dunn, The Catholic Church and Russia, op. cit., p. 80; S. P. Ramet, Catholicism and politics in communist societies, Durham 1990, p. 51-53; A. Kozyrska, Arcybiskup Edward Ropp. Życie i działalność (1851-1939), Lublin 2004, p. 174-183; Ch. L. Zugge, The forgotten: Catholics of the Soviet Empire from Lenin through Stalin, Syracuse 2001, p. 180-189.

${ }^{16}$ D. Szpoper, Diecezja mińska pod rzadami biskupa Z. Łozińskiego, in: Kościół a państwo na pograniczu polsko-litewsko-białoruskim. Źródła i stan badań, edit. M. Kietliński, K. Zychowicz, W. Śleszyński, Białystok 2005, p. 248.

17 K. R. Prokop, Sylwetki biskupów tuckich, Biały Dunajec-Ostróg 2001, p. 197-198.

${ }_{18}$ W. Rosowski, The History of the Roman Catholic Diocese of Kamianets in the years 19181941, op. cit., p. 76-78.

19 О. А. Лиценбергер, Римско-католическая Церковь..., р. 347.

${ }^{20}$ Р. Колупаев, Сливовский Кароль, in: Г. Церова and others (ed.), Католическая энциклопедия, v. 4, Москва 2011, col. 873-874. 
from the moment of his internment in the village of Sedanka in 1923 till his death in January 1933. There was only one bishop on the territory of the USSR who was not confined - the retired bishop of Tiraspol, Anton J. Zerr. He was living in Feodosyia parish in Crimea, but he was not performing any administrative work till his death in 1934 (he gave ordination in secret) ${ }^{21}$.

As all attempts to reach an agreement with the Soviet Union concerning the proper relationship between the state and the Church came to nothing, Pope Pius XI decided to create smaller districts, without cancelling previous administrative structure. The administrative functions of these districts were assigned to priests secretly nominated and consecrated by the papal delegate, bishop Michael d'Herbigny. During his two journeys around the USSR (III-V, VIII-IX 1926) he consecrated four bishops and nominated all apostolic administrators (four bishops, and seven priests). After the disclosure of their posts, they were all arrested, except for the French bishop Pie-Éugène Neveu ${ }^{22}$.

The situation of the Catholic Church in the Soviet Union after the PolishSoviet War was far from being stable. Besides the anti-religious activities of the Soviet authorities, which at first limited the ministry of the Church, and later on aimed at closing down all places of worship, the number of the faithful and priests decreased, as a result of their departure to Lithuania and Poland $(1,260,000$ people left the region, including 469 of the Polish people $)^{23} \cdot 1,663,000$ of the faithful of the Latin rite stayed in the area of the USSR. As far as nationalities are concerned, they were: Polish, German, Lithuanian, Latvian, Belarusian, Armenian, Georgian, and Russian. The most numerous group were Poles, who encompassed from $75 \%$ to $80 \%$ of all the faithful. In the west of the Soviet Union, where the Polish people were an autochthonous nation, they comprised

${ }^{21}$ R. Dzwonkowski, Losy duchowieństwa katolickiego w ZSSR 1917-1939. Martyrologium, Lublin 1998, p. 529; P. Nitecki, Biskupi Kościoła Katolickiego w Polsce w latach 965-1999. Stownik biograficzny, Warszawa 2000, col. 514.

22 J. Dębiński, Kościót katolicki w Rosji, „Studia Włocławskie” 14 (2012), p. 478; D. J. Dunn, The Catholic Church and Russia, op. cit., p. 86-87; H. Stehle, Tajna dyplomacja Watykanu. Papiestwo wobec komunizmu (1917-1991), Warszawa 1993, p. 79-87; Ch. L. Zugge, The forgotten: Catholics of the Soviet Empire from Lenin through Stalin, op. cit., p. 228-240.

${ }^{23}$ A. Czubiński, Koncepcje geopolityczne Pitsudskiego w latach 1918-1921, in: A. Czubiński, Ewolucja systemu politycznego w Polsce w latach 1914-1998, v. 1, Odbudowa niepodległego państwa i jego rozwój do 1945 r., part 1, Zbiór studiów, 1999, p. 88 (mps); A. Patek, Polska diaspora w Rosji Radzieckiej i ZSRR, in: Polska diaspora, edit. A. Walaszka, Kraków 2001, p. 296; D. Szpoper, Diecezja mińska pod rządami biskupa Z. Łozińskiego, op. cit., p. 242-243. 
$90 \%$ of all the Catholics ${ }^{24}$. The census carried out in 1926 showed that in the country of workers and peasants there were 790,000 Poles (in the Ukrainian SSR - 476,000; the Belarusian SSR - 97,000) ${ }^{25}$. Contemporary researchers claim that these numbers drift away from the factual number of people connected and associated with Poland (in Ukraine the number of the Polish was not lower than 650,000$)^{26}$. Germans predominated only in the diocese of Tiraspol and in the Apostolic Vicariate of Crimea and Caucasus. They comprised $60 \%$ of the adherents in these particular territories ${ }^{27}$. The above mentioned census showed that there were 1,238,000 Germans (about 25\% of them Catholic) ${ }^{28}$. The nationality of the faithful and the clergy was an important reason for the extermination of the Catholic Church by the Soviet authorities.

Despite the war, terror and the leaving of the clergy from the Soviet Union, there still were about 420 priests of the Latin rite in above mentioned parishes and vicariates in the mid -1920s. They were of different nationalities: Polish, Lithuanian, German, Latvian, Belarusian, Armenian, Georgian, Russian and Ukrainian. Several priests came from western Europe. However, the Polish people were the most numerous nationality, born in the territories of eastern Belarus and Ukraine, which were passed on to Russia during the Partitions of Poland. Germans born in the Volga region and in the south of Ukraine were the second most numerous group, the third being the Lithuanians and

${ }^{24}$ S. Fil, Na syberyjskim trakcie. Polacy w Kraju Tiumeńskim, Warszawa 1999, p. 79; R. Dzwonkowski, Kościól katolicki..., op. cit., p. 43; M. Iwanow, Z. J. Winnicki, Katolicy na terenie byłego ZSRR: kontrowersje wokół liczebności-szacunki bieżace i potencjalne, in: E. Walewander (ed.), Odrodzenie Kościoła katolickiego w Bytym ZSRR. Studia historyczno-demograficzne, Lublin 1993, p. 183; M. Korzeniowski, Białoruś i Białorusini na tamach prasy polskiej $w$ Rosji w latach I wojny światowej, „Białoruskie Zeszyty Historyczne” 23 (2005), p. 32; J. M. Kupczak, Polacy na Ukrainie 1921-1939, Wrocław 1994, p. 50.

${ }^{25}$ P. Eberhardt, Polska ludność kresowa. Rodowód, liczebność, rozmieszczenie, Warszawa 1998, p. 61, 182; A. Patek, Polska diaspora..., p. 297; M. Sobczyński, Polska autonomia narodowościowa w ZSRR, in: H. Kubiak, T. Paleczny and J. Rokicki (eds.), Mniejszości Polskie i polonia w ZSRR..., Wrocław-Warszawa-Kraków 1992, p. 56.

${ }^{26}$ R. Dzwonkowski (ed.), Głód i represje wobec ludności polskiej na Ukrainie 1932-1947, Lublin 2004, p. 24; M. Iwanow, Pierwszy naród ukarany. Polacy w Związku Radzieckim 19211939, Wrocław 1991, p. 72, 82-83.

${ }^{27}$ L. Gędłek, T. Krzyżanowski, M. Żurek, Zarys historii diecezji odesko-symferopolskiej, Odessa-Kraków 2011, p. 29.

${ }^{28}$ Всесоюзная перепись населения 1926 года. Национальный состав населения по республикам СССР, in: www.demoscope.ru/weekly/ssp/ussr_nac_26.php (21.03.2013); О. Лиценбергер, Антирелигиозные кампании, www.rusdeutsch-panorama.ru/jencik_statja. php?mode=view\&site_id=34\&own_menu_id=4532 (25.03.2013). 
the Belarusians born in Lithuania and Belarus guberniya. 91\% of the clergy came from Polish families ${ }^{29}$ in the diocese of Minsk in 1918. In the diocese of Kamianets $86 \%$ of priests claimed to be Polish, the second nationality was Lithuanians and Samogitians, loyal to the Polish adherents, but creating 'their own national atmosphere ${ }^{30}$ in the presbyteries. In the diocese of Tiraspol 73\% of the clergy declared to have been German ${ }^{31}$.

The history of repressions organized by the Soviet authorities towards the Roman Catholic Church can be divided into five stages:

1. 1921-1925: the first organized activities of the Soviet authorities,

2. 1927-1928: the climax of the activities hindering any influence of the clergy on the faithful and holding the Christian ministry back,

3. 1929-1936: repressions connected with the idea of the collective farming,

4. 1937-1939: massive liquidation of the clergy living in exile, in labour camps, imprisoned or free ${ }^{32}$.

During twenty-five years of Soviet rule, 500 priests had been repressed in many different ways. Those who were persecuted during the revolution, domestic war and the Polish-Soviet conflict, fled the Soviet Union fearing for their lives. There were fifty-three priests $(56 \%)^{33}$ outside the diocese of Kamianets in 1926. There were 154 priests (68\%) in 1934 outside the diocese of Mohilev from 228 who were shown in the census: one hundred and six were staying in Poland, thirty four in Lithuania, five in Latvia, five in the USA, two in Italy, one in the $\mathrm{UK}$, one in $\mathrm{China}^{34}$. Abandoning of the parishes and seeking rescue in "the free world' was not unambiguous to evaluate. Because of the various circumstances, each time the Church authorities demanded a permission for the departure from the superiors, an arbitrary departure was treated as an offence carrying a penalty of suspension latae sententiae (ipso facto). The risk of being arrested and losing

${ }^{29}$ My own estimates based on The catalogues of the clergy and published biograms.

${ }^{30}$ W. Rosowski, The History of the Roman Catholic Diocese of Kamianets in the years 19181941, op. cit., p. 155.

31 Ł. Gędłek, T. Krzyżowski, M. Żurek, Zarys historii diecezji odesko-symferopolskiej, op. cit., p. 29.

32 А. Чернышев, Репрессивная политика совецкого государства в отношении римскокатолической Церкви в енисейской губернии (1917-1939 годы), in: Ofiary w imperium..., p. $470-471$.

${ }^{33}$ W. Rosowski, The History of the Roman Catholic Diocese of Kamianets in the years 19181941, op. cit., p. 150.

${ }^{34}$ Elenchus cleri et ecclesiarum archidioeceseos Mohiloviensis in Russia in diem 5 decembris 1931, Varsaviae 1932, p. 13-25. 
one's life were accepted as justified reasons for leaving pastoral outposts. It is distinctive that among the clergy who stayed in the Soviet Union after 1921, there were only a few who decided to escape to Poland or Lithuania, although staying in the USSR was tantamount to poverty, hunger, prison and even death. All declarations of respecting religious freedom were in vain although it was pointed out in the text of the Peace of Riga (18 March 1921) signed and ratified by the All-Russian Central Executive Committee (14 April 1921) and by the Ukrainian Central Executive Committee (17 April 1921) ${ }^{35}$.

For example: after the establishing of the Polish-Soviet border there were forty-six priests on the territory of the diocese of Kamianets. From the year 1927 the number of priests systematically decreased, as a result of arrests and exile to the labour camps. In 1931 there were thirty-one priests who were not imprisoned. A year later, after a huge wave of arrests, only fifteen priests were performing pastoral duties. During the next massive arrests in 1935 only three priests were spared $^{36}$. However, they did not stay free for long. They were arrested during the so called 'Polish operation' in 1937. Before the outbreak of World War II only one priest was not put in jail, and that was Władysław Dworzecki, who was paralyzed and therefore allowed by the Soviet authorities to stay in Kamianets Podolsky under the care of his house-keeper, but without the possibility of pastoral work ${ }^{37}$.

The repressions against the Roman Catholic Church were the result of the Soviet antagonistic relation to religion and religious congregations. Religion was perceived as an element of the old order and so it was decided to gradually liquidate religious units, which was tantamount to the annihilation of the clergy as a social group ${ }^{38}$. These activities involved the introduction of the antireligious legislation based on the legal acts of the Paris Commune of $2^{\text {nd }}$ April $1871^{39}$. Churches and religious units were deprived of the legal personality and of proprietorship. All churches, church premises together with their content

${ }^{35}$ K. D. Croll, Soviet-Polish relations, 1919-1921, Glasgow 2008, p. 214-216 (mps).

${ }^{36}$ W. Rosowski, The History of the Roman Catholic Diocese of Kamianets in the years 19181941, op. cit., p. 150-151.

${ }^{37}$ R. Dzwonkowski, Losy duchowieństwa..., p. 219-219.

${ }^{38}$ A. Patek, Położenie prawne Kościoła katolickiego na Wschodzie w okresie międzywojennym $w$ świetle oficjalnego ustawodawstwa wyznaniowego władz sowieckich, in: Kościót katolicki na Syberii..., p. 432.

${ }^{39}$ M. T. Straszewski, Polityka wyznaniowa europejskich państw socjalistycznych, w: M. T. Staszewski, W. Mysłeka (eds.), Polityka wyznaniowa. Tło-warunki-realizacja, Warszawa 1975, p. 8283; K. Szymański, Procedury ideologiczne wobec religii w ZSRR, in: P. Jaroszyński and others (eds.), Polityka a religia, Lublin 2007, p. 338. 
were nationalized. Church institutions were closed down. Congregations were forbidden not only to manage schools but also to teach children the principles of faith ${ }^{40}$. Charitable activities were also made illegal ${ }^{41}$. These actions were put in practice on the grounds of the following: the decree About land passed by during the $2^{\text {nd }}$ All-Russian Congress of Soviets on the $8^{\text {th }}$ September $1917^{42}$, the resolutions about subjection of all church schools to the Commissariat of Education, issued by the Soviet Commissariat of Education on the $11^{\text {th }}$ December $1917^{43}$, the decree About civil marriages, children, and book-keeping of the civil registry issued on the $18^{\text {th }}$ December 1917 by the All-Russian Central Executive Committee and the Council of People's Commissars ${ }^{44}$, the decree of the Council of People's Commissars of the $20^{\text {th }}$ January 1918 About freedom of conscience and religious congregations (sometimes published as About separation of the Church from the State and school from the Church, issued on the 23rd January 1918) ${ }^{45}$. A lot of imprecise legal executive provisions allowed the authorities to terminate religious institutions and also to control any signs of religious life of an individual, together with all external religious manifestations and the activities of the Church institutions ${ }^{46}$.

${ }^{40}$ H. Stehle, Tajna dyplomacja Watykanu. Papiestwo wobec komunizmu (1917-1991), Warszawa 1993, p. 18.

${ }^{41}$ О. А. Лиценбергер, Римско-католическая Церковь..., p. 186-187; A. Patek, Położenie prawne Kościoła katolickiego na Wschodzie ..., p. 434-435.

42 Декрет о земле, in: Декреты Советской власти, v. 1, 25 октября 1917 г. - 16 марта 1918 г., edit. Л. Н. Обачкина. С. Н. Валка, Л. С. Гапоненки, Москва 1957, p. 18.

43 Постановление о передаче всех церковных икол в Комиссариат просвещения, т.е. лишение Церкви всех семинарий, училищ, академий и всего связанного с ними имущества, in: Декреты Советской власти..., p. 210-211.

44 Декрет о гражданском браке, о детях и о ведении книг актов состояния, in: Декреты Советской власти ..., p. 247-249.

${ }^{45}$ Декрет о свободе совести, иерковных и религиозных обществах, in: Декреты Советской власти..., p. 373-374; Декрет об отделении церкви от государства и школы от церкви (23 I 1918), in: Русская Православная..., оp. cit., p. 113-114; J. Wróbel, Polityka ZSRR wobec Kościoła katolickiego w latach 1917-1939, in: E. Walewander (ed.), Polacy w Kościele katolickim w ZSRR, Lublin 1991, p. 88.

46 Постановление от 24 VIII 1918 г. о порядке проведения в жизнь декрета „об отделении церкви от государства и школы от церкви" (инструкция), in: www.libussr.ru/doc_ussr/ ussr_347.htm (20.03.2013); R. Dzwonkowski, Kościót katolicki..., p. 64; И. Цеплак, В Отдел Управления Петросовета, 24 II 1922. Симптомы религиозной нетерпимости болельщиков, in: Католическая Церковь накануне револючии 1917 года. Сборник документов, Люблин 2003, p. 661-664; Б. Чаплицкий, История гонений. Католическая церковь в Росси, in: Б. Чаплицкий, И. Осипова, Книга памяти. Мартироло католической Церкви в СССР, 
In addition, massive propaganda activities were undertaken to promote the atheisation of society. Such actions intensified from April 1923, after the $12^{\text {th }}$ congress of the Russian Communist Party (of Bolsheviks). It was accepted at the congress that apart from massive repressions of the security service, it would be necessary to multiply anti-religious actions, coordinated by an institution created especially to do that, which would publish books and magazines $^{47}$. Yemalyan Yeroslavsky was given the job of the organization of "the anti-religious front" ${ }^{\prime \prime}$. In December 1922 the newspaper Bezbozhnik ("The Godless") ${ }^{49}$ was published, while the Society of the Godless magazine was established two years later. It was restructured into the Union of Bezbozhnik of the USSR in 1925. Moreover, by the year 1932, five and a half million people had become members of the union; sometimes they were signed up in advance by the party, trade unions or by office-workers ${ }^{50}$. Besides The Godless, which was published in one million copies in several editions and different languages, there also appeared magazines like: The Antireligious, Young Godless, Rural Godless and Militant Atheism. Anti-religious actions were supervised by the Bolshevik party, and supported by trade unions and by the Commissariat of Education ${ }^{51}$. Many poets and writers were involved in fighting against religiousness ${ }^{52}$.

Москва 2000, p. XXIII-XXV, XLI; K. Szymański, Procedury ideologiczne wobec religii w ZSRR, in: P. Jaroszyński and others (eds.), Polityka a religia, Lublin 2007, p. 341-342.

${ }^{47}$ R. Dzwonkowski, Losy duchowieństwa..., p. 71; P. Grochowski, Wizerunek Zachodu na tamach czasopisma „Bezbożnik” 1925-1929, Kraków 20012, p. 15-16 (mps); A. Luukkanen, The Party of Unbelief. The Religious Policy of the Bolshevik Party 1917-1929, Helsinki 1994, p. 157; J. Szymański, Historia laicyzacji. Skala oddziatywania antyreligijnego na sytuację Kościoła katolickiego na Wschodzie, „Sympozjum” 9 (2005), no. 1 (14), p. 12-13.

${ }^{48}$ G. Przebinda, Jarosławski Jemieljan Michajłowicz, in: G. Przebinda, J. Smaga, Leksykon. Kto jest kim w Rosji po 1917 roku, Kraków 2000, p. 117.

49 И. В. Кузнецов, История отечественной журналистики (1917-2000), in: www.evartist. narod.ru/text8/01.htm (24.07.2012).

${ }^{50}$ P. Grochowski, Wizerunek Zachodu na łamach czasopisma ,Bezbożnik” 1925-1929, op. cit., p. 16; Б. Н. Коновалов, Союз воинствующих безбожников, in: Вопросы научного атеизма, Москва 1967, p. 287; J. Szymański, Historia laicyzacji. Skala oddziaływania antyreligijnego na sytuację Kościoła katolickiego na Wschodzie, op. cit., p. 13.

${ }^{51}$ D. J. Dunn, The Catholic Church and Russia, op. cit., p. 85; J. Szymański, Atheisation of children and the young in Soviet system of education (Vinnytsya oblast in Podolia 19441964), „Ateneum Kapłańskie” 3 (565) (2003), v. 140, p. 489-503; J. Szymański, Ideological procedures towards religion in the USSR, in: Politics versus religion, ed. P. Jaroszyński, Lublin 200, p. 343-344.

52 А. Венгер, Рим и Москва 1900-1950, Москва 2000, р. 232-234. 
The intentions of the Bolsheviks towards the Church left no space for illusion as it was pictured in the first Constitution of the Soviet Russia (passed on the $10^{\text {th }}$ July 1918) and the instructions of the Central Executive Committee of the Congress of Soviets about elections to the Congress of Soviets (signed on the $13^{\text {th }}$ October 1925). The clergy was deprived of any civil rights (they were called 'liszeńcy') as people who 'were harmful to the interests of the socialist revolution' (par. 23). They were deprived of the active and passive right to vote (par. 65), but also of the food coupons, medical care and government housing. However, they had to fulfill all the civil duties imposed on them: they paid taxes, were obliged to auxiliary forces and public duty (digging ditches, cleaning of cesspits, waste and garbage disposal and snow fighting $)^{53}$. As a group belonging to 'non-wage earners' they paid extremely high taxes as well as many fees connected with church activities, higher rent and power bills. Poverty and hunger became part of their everyday life. The majority of priests were moved from the parishes, and they therefore stayed at their parishioners' who were able to resist the authorities ${ }^{54}$.

In addition, there appeared constant repressions of the State Political Directorate, which were designed to keep the clergy in permanent anxiety. The Directorate had plenty of means to do that. They mainly used: constant invigilation of the priests' personal life, mail, all their contacts and pastoral service and frequent visits to the office of the Directorate. The first question during the investigation that was dangerous to answer was the attitude towards the Soviet authorities. The methods of badgering were among others the accusations of the moral conduct appearing in the local press, publication of the photomontage with women, accusations of alcoholism, hooliganism, theft, bribery etc. The trials were organized and conducted for these particular reasons ${ }^{55}$. Needless to say, these accusations were proved groundless.

Basically, during the first years of the Soviet rule, anti-religious activities were yet not well-organized. There appeared these acts of terror strictly connected with the Revolution: hostage arrests ${ }^{56}$; the 'enemy of the people' were apprehended by Cheka (Emergency Commission); murders and crimes done by

${ }^{53}$ Patek, Położenie prawne Kościoła katolickiego na Wschodzie..., p. 444.

${ }^{54}$ Z dziejów Kościoła rzymskokatolickiego w Rosji Sowieckiej ..., p. 201.

${ }_{55}$ R. Dzwonkowski, Kościót katolicki..., p. 202; R. Dzwonkowski, Losy duchowieństwa, p. 73. Among those accused of immorality were: P. Kaziunas, K. Mustejkis, Ibidem, p. 286, 361.

${ }^{56}$ Including: J. Baumtrof, J. Bikszys, P. Birnik, J. Duckart, F. K. Kimaszewski, B. Kocięski, N. Kraft, J. Król, P. Krzystek, A. Szczawiński, K. Weissenburger. Б. Чаплицкий, И. Осипова, ор. 
the Red Army ${ }^{57}$, party activists and officers of $\mathrm{Cheka}^{58}$ and also by anarchists. Assaults and sacking initiated by plain bandits happened on a regular basis ${ }^{59}$. A large group of the imprisoned clergymen were those who opposed the requisition ${ }^{60}$ of valuable liturgical vestments ${ }^{61}$.

As the political situation in the country stabilized, the actions against the Church and the clergy did not change. Rather, they became more organized and were undertaken because of political grounds. Repressions against the clergy were supposed to limit their influence on people, making it easier for the authorities to impose atheism and sovietism ${ }^{62}$. For these reasons, any pastoral activity was treated by the authorities as a political activity. It was enough to demonstrate that a priest was preaching to children or youth to sentence him to eight years in a labour camp ${ }^{63}$.

cit., p. 27, 28, 43, 98-99, 100; R. Dzwonkowski, Losy duchowieństwa..., p. 155-156, 163-164, 215, 290, 295, 303-304, 462; О. А. Лиценбергер, Римско-католическая Церковь..., p. 214.

${ }^{57}$ Among others: Sz. Barbarski, G. Beratz, J. Duckart, F. Grabowski, A. Hajduk, J. Kaiser, W. Klamm, F. Kołomyjski, B. Knobelsdorf, A. Kowalski, N. Kraft, W. Łotarewicz, A. Małaczyński, K. Marcinian, W. Mikołajtis, B. Pędzich, S. Szulborski, K. Weissenburger. Б. Чаплицкий, И. Осипова, ор. cit., p. 26-27, 49, 57, 66, 83, 94, 95-96, 108; R. Dzwonkowski, Losy duchowieństwa... p. 46, 277, 288, 292, 295, 297, 303, 331, 347, 348, 357, 390, 467, 510; S. Leończyk, Polacy - mieszkańcy wsi syberyjskiej. Walka o przeżycie 1917-1938, in: Ofiary imperium. Imperia jako ofiary. 44 spojrzenia, edit. A. Nowak, Warszawa, 2010, p. 461; M. Tokarrzewski, Przyczynek do historii męczeństwa Kościoła rzymsko-katolickiego w diecezji kamienieckiej i łucko-żytomierskiej 1863-1930, Łuck 1933, p. 28.

${ }_{58}$ Among others: Sz. Babarski, K. Butyniec, N. Dyakowski, Cz. Kuktarewicz, A. Radziuk, E. Światopełk-Mirski, J. Weber. Б. Чаплицкий, И. Осипова, ор. cit., p. 14, 35, 41, 64; R. Dzwonkowski, Losy duchowieństwa ..., p. 146-147, 186, 219-220, 316, 404, 476-477, 506-507.

${ }^{59}$ Among others: K. Baran, C. Bujalski, J. Hoffmann, J. Kniukszta, F. Krygielski, B. Lisowski, K. Mazur, G. Sauer, T. Szeptycki. Б. Чаплицкий, И. Осипова, op. cit., p 17, 35-36, 75, 94, 102, 107, 114; R. Dzwonkowski, Losy duchowieństwa..., p. 150, 182-183, 249, 291, 307, 324-325, 353354, 425-426, 465; О. А. Лиценбергер, Римско-католическая Церковь..., p. 209-210, 249.

${ }^{60}$ Архивы Кремля. Политбюро и Церковь 1922-1925 г2. Дело №23. «Об изъятии иерковных иенностей и колоколов», in: www.dl.unilib.neva.ru/d1/327/Theme_10/Sources/Soc polit_life/Kremls_archievs.htm (21.03.2013). Лиценбергер, Римско-католическая Церковь..., p. 233-238; R. Pipes, Rosja bolszewików, p. 370-379, Warszawa 2005.

${ }^{61}$ Including: J. Berezowski, L. Bujnowski, W. Bujnowski, W. Dworzecki, A. Kowalski, S. Krygielski, J. Lewiński, A. Lisowski, A. Liniewicz, J. Łukasz, A. Niedzielski, F. Lubczyński, M. Rutkowski, J. Scheiner, W. Szymański, W. Szymański, R. Szyszko-Bohusz, M. Tomaszewski, S. Truskowski. Б. Чаплицкий, И. Осипова, ор. cit., p. 35, 59-60, 95-96, 108-109, 111-113; R. Dzwonkowski, Losy duchowieństwa ..., 159-160, 184-185, 298, 307, 322, 323, 324-325, 326, 334, 371, 378, 419, 428, 472, 484, 489-490; О. А. Лиценбергер, Римско-католическая Церковь..., p. 231-232.

${ }^{62}$ H. Stroński, Represje stalinizmu wobec ludności..., p. 75.

${ }^{63}$ See: P. Aszemberg, J. Cimaszkiewicz, W. Dejnis, A. Liniewicz, F. Lubrzyński, A. Samosenko, A. Traczyński. Б. Чаплицкий, И. Осипова, op. cit., p. 13-14, 166; R. Dzwonkowski, Losy 
These actions were led by the national security organs supported by all national offices, anti-religious organizations and educational and social activists. Badgering by investigations, questionings, controls, and taxation usually ended in arrest and the sentence to labour camps ${ }^{64}$.

The group trials of priests and some of the most active Catholics were organized in this period of time under the pretext of fighting against counterrevolutionary circles. The first of such lawsuits took place in 1922 and 1923 in Yaroslavl upon the Volga river, Minsk, Kamianets-Podolsky, and Moscow ${ }^{65}$.

In the years 1924-1926, many priests, whom the authorities wanted to force to secret cooperation, were put in jail ${ }^{66}$. However, the majority of the methods imposed on them failed. Therefore, it was necessary to resort to the most drastic manners - imprisonment and fear of death or a long sentence to labour camps. The procedures practised to gain the desired effect were: blackmail, physical and psychological pressure, promises of immunity, threats of anonymous death, imprisonment, exile to the Gulag of the charged person himself and his closest relatives ${ }^{67}$. As a result of these repressions, many priests fell ill with mental disorders ${ }^{68}$. Despite having been arrested, the majority of the priests backed up from the cooperation with the authorities, and unmasked in front of the other priests, they wrote official notes about the annulment of any agreement they could have made, or they simply did not cooperate by avoiding the visits of the security services ${ }^{69}$. The authorities also aimed at the

duchowieństwa. 142, 323, 327-328, 424, 485; О. А. Лиценбергер, Римско-католическая Церковь..., р. 203.

${ }^{64}$ M. in. P. В. Kapusta, L. Warpechowski. Б. Чаплицкий, И. Осипова, op. cit., p. 86; R. Dzwonkowski, Losy duchowieństwa, p. 73, 279, 498.

${ }^{65}$ Dzwonkowski, Losy duchowieństwa, p. 77; F. Rutkowski, Arcybiskup Jan Cieplak 18571926, Warszawa 1934, p. 260-183; М. В. Шкаровский, Н. Ю. Черепенина, А. К. Шикер, Римско-католическая Церковь на Северо-Западе России в 1917-1945 г2., Санкт-Петербург 1998, p. 25-19; H. Stehle, Tajna dyplomacja Watykanu. Papiestwo wobec komunizmu (1917-1991), Warszawa 1993, p. 45-47.

${ }^{66}$ See A. Fedukowicz, Z. Kwaśniewski, K. A. Łupinowicz, K. Nanowski, J. Słowiński, J. Trojga. Б. Чаплицкий, И. Осипова, op. cit., p. 110-111, 171-172; R. Dzwonkowski, Losy duchowieństwa. 73, 228-230, 318-319, 337-338, 362-363, 450-452, 488-489.

${ }^{67}$ R. Dzwonkowski, Kościót katolicki.., p. 211.

${ }^{68}$ See: A. Dołęga-Kelus, D. Mailland, S. M. Sołowiow, J. Trojga, A. Żukowski. Б. Чаплицкий, И. Осипова, ор. cit., p. 73, 90; R. Dzwonkowski, Losy duchowieństwa, 286-287, 340-341, 448449, 488-489, 539-540.

${ }^{69}$ R. Dzwonkowski, Kościót katolicki..., p. 211-212; W. Rosowski, The History of the Roman Catholic Diocese of Kamianets in the years 1918-1941, op. cit., p. 182-185. 
apostasy of the clergy, which was supposed to accelerate mental isolation of the faithful from their priests and make them leave the Church for $\operatorname{good}^{70}$. In spite of the commitment of the militia and the political machinery, few priests decided to leave their posts ${ }^{71}$.

Many group trials took place in the years 1926-1928 when priests were accused of anti-soviet and counter-revolutionary activity only because of their pastoral duties. Articles 119 and 120 of the RSFSR (Russian Soviet Federative Socialist Republic) Penal Code from 1922 and 1926 were used to gain this aim. The first of the articles dealt with the punishibility of using 'religious superstitions' to overthrow the workers' and peasants' authority, and the second one forbade the teaching of religion to children and the young ${ }^{72}$ Several dozen priests were arrested and brought to trial on the basis of these $\operatorname{articles}^{73}$. According to priest Dzwonkowski's research, at least sixty-seven priests were arrested at that time (1926 - twenty-two, 1927 - twenty-eight, 1928 - seventeen); they were sentenced from five to ten years in the Gulag for espionage and counter-revolutionary activity ${ }^{74}$. The apprehensions of the clergy lasted throughout all the years of Soviet rule, but in connection with the implementation of the collective farming from 1929 to 1931 these actions intensified. A resolution of the Central Executive Committee and the Council of People's Commissars from the $9^{\text {th }}$ April 1929 About religious congregations ${ }^{75}$ was used in these actions, as well as the resolution of the Congress of Peoples' Commissars form the $18^{\text {th }}$ May 1929 which strongly supported any anti-religious activities of the state ${ }^{76}$ together with About the fight with counter-revolutionary elements in the managing organs of the religious congregations issued by the

${ }^{70}$ R. Dzwonkowski, Losy duchowieństwa..., p. 75-76.

${ }^{71}$ W. Chrzczonowicz, E. Perkowicz, J. Romaniuk, A. Sak, B. Wołyniec, J. Żamojtuk. Б. Чаплицкий, И. Осипова.

72 J. Szymański, Historia laicyzacji..., p. 11.

${ }^{73}$ See: P. Aszemberg, J. Cimaszkiewicz, W. Dejnis, J. Furch, J. Kozakiewicz, A. Liniewicz, F. Lubrzyński, J. Pawłowicz, A. Samosenko, A. Staub, A. Traczyński. Б. Чаплицкий, И. Осипова, op. cit., p. 166; R. Dzwonkowski, Losy duchowieństwa..., p. 142, 237, 299-300, 323, 327-328, 387-388, 424, 485; О. А. Лиценбергер, Римско-католическая Церковь..., p. 203, 248.

${ }^{74}$ R. Dzwonkowski, Losy duchowieństwa..., p. 79.

${ }^{75}$ Хронологическое собрание законов, указов Президиума Верховного Совета и постановлений Правительства РСФСР, v. 2, 1929-1939, Москва 1959, p. 29-45.

${ }^{76}$ Постановление XIV Всероссийского Съезда Советов Рабочих, Крестьянских, Казачьих и Красноармейских Депутатов..., www.constitution.garant.ru/history/ussr-rsfsr/1925/postanovleniya/3946674/ (20.03.2013). 
Central Executive Committee and the Council of People's Commissars on the $11^{\text {th }}$ February $1930^{77}$. The blame for inadequate results of collective farming on the territory of western Ukraine and Belarus was placed on the resistance of the Catholics, who were inspired by the Polish and German clergy ${ }^{78}$. According to Jan Świderski, the administrator of the diocese of Kamianets at that time: the 'liquidation (of Kulaks) had nothing to do with the Church, in reality, however, the practice showed that huge number of the congregation members as well as priests were labeled as Kulaks ${ }^{79}$. As Mikołaj Iwanow writes: 'The authorities' policy aimed at the liquidation of all the Catholic priests who were able to have independent opinion and resisted atheization' ${ }^{80}$. All priests who were caught helping the starving or distributing supplies from outside the country were put in jail ${ }^{81}$. All clergymen who were arrested at that time were sentenced to death by an administrative procedure. In most cases, however, the execution was not carried out. Such sentences were automatically changed to eight or ten years in a labour camp. Over $90 \%$ of priests were kept in the Gulag and in regular prisons in 1932.

The incarceration of a priest was tantamount to the closure and proscription of the parish and the painful repression of the adherents who tried to look after the churches. There were thirty open churches and chapels together with sixteen priests in service in 1932 (from 331 present in 1921) in the Archdiocese of Mohilev. According to the German Ministry of Foreign Affairs, there were only twenty five priests in Ukraine who were not imprisoned ${ }^{82}$.

Clergymen, who were sentenced to labour camps or exile, were treated as especially dangerous. Even the sick and the elderly were used for the hardest work. They were deprived of all rights even of the right to exchange correspondence. After serving their time (sentence usually in administrative proceedings) they were exiled to places of seclusion for more years. Rarely

77 О. А. Лиценбергер, Римско-католическая Церковь..., p. 273.

${ }^{78}$ O. Auhagen, Schicksalwende des Russlanddeutschen bauerntums in den Jahren 1927-1930, Lipzing 1942, p. 189-190.

79 Z dziejów Kościoła rzymskokatolickiego w Rosji Sowieckiej..., p. 189.

${ }^{80}$ M. Iwanow, Pierwszy naród ukarany..., p. 319.

${ }^{81}$ See: A. Baumtrog, R. Glassner, J. Karpiński, W.W. Klöpfer, J. Kruschinski, Z. Klemczynski, J. Tauberger. Ю. Білоусов, ор. cit., p. 182-185, 186-188; Б. Чаплицкий, И. Осипова, ор. cit., p. 21, 54-55, 86-87, 92-94; R. Dzwonkowski, Losy duchowieństwa ..., p. 153-155, 281, 290-191, 288-289, 305-306, 469-480; О. А. Лиценбергер, Римско-католическая Церковь..., р. 271.

${ }^{82}$ H. Kurz, Christen hinter dem Eisernen Vorhang. Die christliche Gemeinde in der kommunisti, Stuttgart 1962, p. 75; О. А. Лиценбергер, Римско-католическая Церковь..., p. 286. 
were there any Catholic congregations in the places of isolation. It was difficult for them to find accommodation or a job, which was tantamount to hunger or slow death ${ }^{83}$. From 1929 to 1931, 142 clergymen were arrested in the territory of the while USSR (1929 - forty-five, 1930 - seventy-four, 1931 - twenty-three) ${ }^{84}$. In the Ukrainian SSR, forty-nine priests were put in jail (in the diocese of Kamianets twenty one priests were Polish ${ }^{85}$. The aim of this action was 'to clear' Podolia of the Polish priests ${ }^{86}$. Some of them were brought to trial in the group lawsuit of priests from the diocese of Zhitomir and Kamianets $\left(21^{\text {st }}-27^{\text {th }}\right.$ June 1930). They were charged with anti-Soviet and counter-revolutionary activities and espionage in favour of Poland. In the diocese of Kamianets, twelve priests were still free ${ }^{87}$; most of them were of Lithuanian or Samogitian origin (they were temporarily spared because of the conflict between Poland and Lithuania about the Vilnius Region) ${ }^{88}$. They could not perform their duties because of old age (six of them) and sickness (three of them) ${ }^{89}$. In fact, this was an action related to the preparation of two big operations of displacement of the Polish people accused of association with the Kulaks and the subversion of the collective farming from the borderline area. 30,000 to 35,000 people connected with the Catholic Church, (sometimes together with their families) were deported to Kazakhstan or Siberia in 1932-1933 and in 1935-1936 ${ }^{90}$. According to Henryk Stroński, from 200,000 to 250,000 Poles were deported, exiled, sentenced to labour camps, put in jail or shot in Ukraine from 1929 to $1939^{91}$.

${ }^{83}$ W. Rosowski, The History of the Roman Catholic Diocese of Kamianets in the years 19181941, op. cit., p. 196.

${ }^{84}$ R. Dzwonkowski, Losy duchowieństwa..., p. 79.

${ }^{85}$ H. Stroński, Represje stalinizmu wobec ludności..., p. 78; Ю. Білоусов, ор. cit., p. 147.

${ }^{86}$ The arrested and sentenced priest were: S. Kasprzykowski, Z. Klemczyński, J. Koziński, J. Krummel, R. Kwaśniewski, J. Lewiński, A. Matuszewski, J. Mioduszewski, K. Naskręcki, A. Pietkiewicz, A. Schönberger, S. Juchniewicz, N. Szczepaniuk, P. Welik, J. Zdaniewicz. Б. Чаплицкий, И. Осипова, оp. cit., p. 76, 92-93, 100-101, 133; R. Dzwonkowski, Losy duchowieństwa ..., p. 284, 288-289, 300-301, 305, 319, 32, 353, 365-366, 391-392.

${ }^{87}$ Z dziejów Kościoła rzymskokatolickiego w Rosji Sowieckiej..., p. 193.

${ }^{88}$ W. Rosowski, The History of the Roman Catholic Diocese of Kamianets in the years 19181941, op. cit., p. 189-191.

${ }^{89}$ Z dziejów Kościoła rzymskokatolickiego w Rosji Sowieckiej..., p. 193.

${ }^{90}$ Gtód i represje..., p. 25-27; W. Rosowski, The History of the Roman Catholic Diocese of Kamianets in the years 1918-1941, op. cit., p. 249.

${ }^{91}$ H. Stroński, Represje stalinizmu wobec ludności polskiej na Ukrainie w latach 1929-1939, Warszawa 1998, p. 53. 
At the same time, the Church life of the diocese of Tiraspol was almost completely liquidated. The reason behind the incarceration of some priests and active adherents of the Catholic Church was the accusation made against them of their involvement in the 'fascist, Catholic, counter-revolutionary formation of Germans in the Volga region's espionage in favour of the Vatican and Germany. Over thirty clergymen were apprehended in connection with this made-up information from the $1^{\text {st }}$ January 1930 to the $1^{\text {st }}$ March $1931^{92}$. After accomplishing the mission of liquidation, as a German member of parliament informed, in 1932 there were only four priests in the Volga region who were not imprisoned; the rest were put in Solovetsky camp (ten) or other places of seclusion (thirteen) ${ }^{93}$.

Clergymen of German origin (who were still free but in exile or did their time in the Gulag or prisons) became an object of interest for the secret service in the years 1935-1936. Priests who were staying in the Volga region, Ukraine, Siberia and Kazakhstan were accused of 'fascist propaganda', 'counter-revolutionary activity', 'espionage', and an active participation in 'the organization of the terrorist network' connected with "Trotskyist centre". Twenty-seven priests were arrested at that time, twelve of whom stood trial in a group lawsuit in Moscow ${ }^{94}$.

The final solution of the problem of the Catholics of the Eastern rite took place in the years 1934-1935. Archbishop B. Remow was sentenced to death in the fourth group trial of the Russian-Catholics in June 1925 and the Catholics who were brought to trial with him were condemned to from three to five years at the Gulag. At the same time, three priests, Dominican sisters of the Eastern rite and a group of adherents were kept in Voronezh. Clergymen were condemned to ten years of the Gulag, sisters to life sentence and secular men for many years at the Gulag ${ }^{95}$.

92 О. А. Лиценбергер, Римско-католическая Церковь..., p. 277-278.

${ }^{93}$ Ibid, p. 260.

${ }^{94}$ The accused were: J. Albert, J. Back, J. Beilmann, P. Eisenkrein, A. Gareis, A. Kappes, W. Klöper, J. Kruschinski, R. Loran, J. Neugum, J. Nold, F. Jaufman, M. Köhler, F. Rauh, C. Reichert, A. Schönberger, K. Schönheiter, J. Zimmerman, J. Wolf. Б. Чаплицкий, И. Осипова, op. cit., p. 22-23, 47, 51-52, 84-85, 107-108, 122-123, 125, 142; R. Dzwonkowski, Losy duchowieństwa ..., p. 79, 135-136, 147, 156, 223, 237-238, 278, 302-303, 305-307, 325-326, 364, 367-368, 373, 405-406, 428-429, 432, 517, 532; О. А. Лиценбергер, Римско-католическая Церковь ...., p. 299-300.

${ }^{95}$ R. Dzwonkowski, Losy duchowieństwa..., p. 80. 
During the 'Great Purge' and the 'Polish operation', as well as the 'German operation', the majority of priests were murdered (120 in all) ${ }^{96}$ and the Church structures were almost completely liquidated. The decisions about apprehension and condemnation were based on the $2^{\text {nd }}$ article 58-10 of the Soviet Penal Code ${ }^{97}$. Only the so-called French churches, used by the western diplomats, were still open in Moscow and Leningrad.

The basis of the anti-Polish activities of the NKVD (Soviet Secret Service) was an operation order number 00485 signed by Nikolai Yezhov on the $11^{\text {th }}$ August 1937 and also 'a secret script dealing with fascist, rebellious, subversive, extremely harmful and espionage actions of the Polish intelligence in the USSR $^{\prime 98}$. The aim of this action was the termination of the Polish Military Organization in industry, transportation and in state and cooperative farms. There was no denying that the lines of this order referred to the annihilation of that part of the Polish minority which was conscious of its nationality. The affiliation to the secret non-existing organization was only a convenient pretext for the ethnic cleansing. All prisoners-of-war who stayed in the USSR, fugitives from Poland, political immigrants, members of anti-Soviet parties and organizations prior to the Revolution, as well as 'the most active anti-Soviet, local, nationalistic element from Polish ethnical region' were apprehended and imprisoned. Every Pole could have been assigned to the last abovementioned group. The order was also a pretext for the extermination of the Catholic clergy and the adherents of faith who were involved in the life of the parishes. As a result of the actions taken, 143,810 cases were considered and 139,835 (97\%) individuals were condemned. 111,091 of the convicts were shot $(79 \%)^{99}$. Not every person convicted under the 00485 order was Polish, however Polish people were among the executed in different operations carried out by the NKVD. The estimated number of Poles murdered during the Great Purge is about 118,000-

${ }^{96}$ Ch. L. Zugge, The forgotten: Catholics of the Soviet Empire from Lenin through Stalin, op. cit., p. $255-278$.

${ }_{97}$ G. P. Cwietkow, Sowieckie ustawodawstwo i organy represji w latach 20-30. XX wieku, „Zesłaniec” (2008), no 33, p. 71-72.

${ }^{98}$ N. Pietrow, Polska operacja NKWD, „Karta” (1993) Nr 11, p. 27-29; Обзор советских pепрессивных кампаний против Поляков и польских гражда, www.memo.ru/history/polacy/ vved/obzor.htm\#_VPID_3 (12.04.2013).

${ }_{99}$ M. Iwanow, Matka premiera. O Polakach w Dowbyszu, „Biuletyn IPN” (2009) no 1-2 (96-97), p. 38; J. Bednark, D. Bojko, W. Chudzik and others (eds.), Polska i Ukraina w latach trzydziestych - czterdziestych XX wieku. Nieznane dokumenty z archiwów stużb specjalnych, v. 8, Wielki Terror: operacja polska 1937-1938, p. 1, Warszawa 2010, p. 71. 
123,000 people $^{100}$. It is worth emphasizing that these numbers show the people convicted but not arrested or apprehended. The execution of the sentences and death penalties caused a 30\% decrease of the Polish population in the territory of the USSR. The loss was severe as the majority of the murdered people were men. Afterwards, the women who survived often had mixed marriages ${ }^{101}$.

Twelve priests of the diocese of Kamianets were imprisoned or exiled in 1937. They were all sentenced to the death penalty from August 1937 to February 1938. Sentences were executed in the place of exile or arrest ${ }^{102}$.

There were yet twenty open churches in Belarus in 1936 and eight priests were in service ${ }^{103}$. They were all arrested in 1937. Five of them were sentenced to death in a group trial in August 1937104. Group trials also took place in Ukraine, in the Gulag and in the places of exile and arrest in Siberia ${ }^{105}$. Eight priests were shot beyond the Urals at that time ${ }^{106}$. The list of the convicted Polish priests and

${ }^{100}$ Н. В Петров., А. Б Рогинский. „Польская операция” НКВД 1937-1938 г2, in: Репрессии против поляков и польских граждан, Москва 1997, p. 22-43; T. Snyder, Skrwawione ziemie. Europa między Hitlerem a Stalinem, Warszawa 2011, p. 124-127.

${ }^{101}$ A. Patek, Polska diaspora..., p. 300-302; Z. J. Peszkowski, S. Z. Zdrojewski, MińskKuropaty, Łódz-Warszawa-Orchard Lake 1999, p. 42-47; Represje przed II wojna światowa, in: S. Ciesielski, W. Materski and A. Paczkowski (eds.), Represje sowieckie wobec Polaków i obywateli polskich, Warszawa 2000, p. 5.

${ }^{102}$ W. Rosowski, The History of the Roman Catholic Diocese of Kamianets in the years 19181941, op. cit., p. 195-196.

${ }^{103}$ M. Iwanow, Pierwszy naród ukarany..., p. 323.

${ }^{104}$ K. Anderkus, P. Awgło, J. Borowik, P. Janukowicz, S. Rajko. R. Dzwonkowski, Losy duchowieństwa..., p. 80-81.

${ }^{105}$ These were murdered in Gulag and other Soviet camps.: E. Bader, P. Baranowski, Sz. Batmaniszwili, A. Bellendir, A. Dornhof, J. Dziemian, A. Dziemieszkiewicz, L. Erk, S. Erojan, M. Fiks, S. Hański, A. Jarmołowicz, B. Juriewicz, A. Kappes, P. B. Kapusta, J. Karpiński, W. Kobeć, J. Kowalski, A. Puczkar-Chmielewski, I. Opolski, J. Paul, P. Riedel, J. Łukasz, J. Łukjanin, P. Madera, J. Mioduszewski, I. Opolski, J. Paul, F. Rauth, P. Riedel, A. Schönberger, P. Schubert, W. Stronczyński, M. Strusiewicz, A. Szaciłło, N. Szczepaniuk, W. Szymański, R. Szyszko, K. Ter, P. Weigel, M. Wolf, J. Żawryd. Ю. Білоусов, оp. cit., 188-189; Б. Чаплицкий, И. Осипова, op. cit., p. 14-15, 18-19, 23-24, 43-44, 50-51, 62-63, 65, 70, 86-87, 95, 108-109-110, 113, 127, 139, 144; R. Dzwonkowski, Losy duchowieństwa..., p. 81-82, 279, 281-282, 293-294, 299, 334-335, 335$336,340-341,358,382-383,387,401-402$, 407, 428-429, 432-433, 455-458, 459-460, 463-464, $469,509,519,533-534$.

${ }^{106}$ E. Akułow, J. Bieniecki, H. Cerpento, B. Dunin-Wąsowicz, A. Markuszewski, A. Traczyński, J. Słowiński, Wł. Żołnierowicz. Ю. Білоусов, op. cit., p. 171-172, 206-207; А. Чернышев, Репрессивная политика совецкого государства в отношении римско-католической Церкви в енисейской губернии (1917-1939 годы), op. cit., p. 472; I. Zaikina, Działalność Delegatury polskiego Czerwonego Krzyża w Moskwie na rzecz duchowieństwa katolickiego w łagrach rosyjskich w latach 1920-1937, in: Kościół katolicki na Syberii. Historia-współczesność-przyszłość, ed. A. Kuczyński, Wrocław 2002, p. 492-497. 
those condemned during the 'Polish operation' is not yet completed. In many cases, Polish and Ukrainian researchers did not manage to specify the place and the date of the priests' death; in fact, we do not have any precise information after the year $1938^{107}$.

At the same time, the operation against the Germans was carried out. It started at night on the $29^{\text {th }}$ July 1937 and it was based on the operation order 00439 signed by Nikolai Yezhov four days earlier. Political fugitives and emigrants with German citizenship were primarily arrested, and later on also German prisoners-of-war of World War I, people of German origin working in the arms industry and transport companies, former workers of the German industrial companies, people who stayed in touch with German diplomats, 'counter-revolutionary' active members of the German autonomous oblast, those imprisoned in the Gulag for espionage in favour of Germany, as well as the wives of the arrested people during the 'German operation'. Considering the slight number of Germans living in the USSR, the operation was not as big as in the case of the 'Polish operation' and at first it did not aim at the total liquidation of German citizens. It became more serious under the influence of the actions undertaken against the Polish people. The statistics, as in the case of the 'Polish operation', deal with the number of condemned and sentenced Germans and not those who were arrested. Incomplete data prepared by contemporary researchers show that during 1937 and 1938 69,000-73,000 Germans were condemned, including 40,000-41,000 within the frame of 'German operation', 20,000-22,000 during 'Kulaks operation', and the rest during another operations carried out by the NKVD. 76,17\% were sentenced to

${ }^{107}$ During 'the Polish Operation', these people were murdered: E. Akułow, K. Anderkus, G. Asłaniszwili, P. Awgło, P. Baranowski, S. Batmawiszwili, A. Bellendir, J. Biernacki, B. Blechman, S. Borecki, J. Borowik, F. Budrys, M. Cakul, H. Cerpento, A. Czerwiński, S. Cybulewicz, S. Demurow, J. Dziemian, A. Dziemieszkiewicz, S. Erojan, L. Gaszyński, A. Gigołaszwili, L. Gozaliszwili, S. Hański, S. Jackiewicz, P. Janukowicz, A. Jarmołowicz, M. Jendruszak, B. Juriewicz, P. Kapusta, J. Karpiński, J. Kowalski, A. Kuczyński, W. Kunda, A. Kurowski, S. Kwaśniewski, Z. Kwaśniewski, J. Łukasz, J. Łukijan, P. Madera, J. Mioduszewski, A. Markuszewski, I. Opolski, E. Perkowicz, J. Pietkiewicz, L. Piotrowski, A. Prytułło, A. PuczkarChmielewski, S. Rajko, S. Sabudziński, K. Siwicki, S. Słowiński, W. Stroczyński, M. Strusiewicz, W. Szczepta, A. Szaciłło, N. Szczepaniuk, W. Szymański, R. Szyszko, T. Karapetian, B. WąsowiczDunin, J. Wersocki, J. Worsław, F. Zabuski, J. Żawryd, W.Żołnierowicz, A. Żukowski. Ю. Білоусов, op. cit, p. 155-156, 156-159, 175-179; Б. Чаплицкий, И. Осипова, op. cit., p. 7-9, 18-19, 23-24, $29,30,35,45,48,50-51,53,62,63,66-67,68-69,70,72,73,74,86-87,89-90,95-96,103$, 104-105, 115, 132-133, 135, 139, 141, 180-181, 182; R. Dzwonkowski, Losy duchowieństwa..., p. $198,268,316,317,318-319,350,392-393,397-398,404,421-422$, 434-435, 505-506, 511-512, $525,536,539-540,574-576$. 
death $^{108}$. As a result of this action, priests of German origin were arrested and put in the Gulag. It concerned almost all priests who had not been killed or died of hunger or over-work earlier ${ }^{109}$.

The fate of the clergymen who stayed in the country of the workers and peasants was tragic. The priest Roman Dzwonkowski, a researcher on the history of the Church in the country of the Bolsheviks claims that from 420 priests living in the USSR after the year 1921 till the end of the Second World War, only twelve priests, who lived and died as free men, survived ${ }^{110}$.

${ }^{108}$ Н. Охотин, А. Рогинский, Из истории “немеикой операщии” НКВД 1937-1938 г2, www. pmem.ru/index.php?id=114 (14.03.2013).

${ }^{109}$ Among those who died at that time, there were: E. Bader, A. Dornhof, L. Erk, M. Fiks, A. Frison, A. Kappes, J. Paul, F. Rauch, P. Riedel, C. Reichert, J. Rosenbach, J. Roth, Schönberger, P. Schubert, A. Wagner, M. Walizer, P. Weigel, M. Wolf, J. Zimmerman. Б. Чаплицкий, И. Осипова, оp. cit., p. 14-15, 36, 37, 47, 65, 144, 145, 146, 173-174; R. Dzwonkowski, Losy duchowieństwa..., p. 405, 313-414, 495, 532, 5474-576.

${ }^{110}$ J. Borodziula, W. Dworzecki, F. Kasperkiewicz, J. Koziński, R. Jankowski, J. Kölsch, R. Loran, M. Marklinger, J. Neugum, A. Samosenko, K. G. Sapariszwili, A. Staub. Ю. Білоусов, op. cit., p. 189-197, 227-228; Б. Чаплицкий, И. Осипова, op. cit., p. 43-44, 91; R. Dzwonkowski, Kościót katolicki..., p. 237; R. Dzwonkowski, Losy duchowieństwa..., p. 167-168, 217-218, 259261, 283-284, 301-302, 325-326, 354, 367-368, 412, 424-425, 453-454. 